\title{
Evaluate the Optimal Future Demand of Water Consumption in Al-Anbar Province in the West of Iraq
}

\author{
Sadeq Oleiwi Sulaiman ${ }^{1}$, Abu Baker A. Najm ${ }^{1}$, Ammar Hatem Kamel $^{1}$, Nadhir Al-Ansari ${ }^{2 *}$ \\ ${ }^{1}$ Department of Dams and Water Resources, College of Engineering, University of Anbar, Ramadi 31001, Iraq \\ ${ }^{2}$ Civil, Environmental and Natural Resources Engineering, Lulea University of Technology, Lulea 97187, Sweden
}

Corresponding Author Email: nadhir.alansari@ltu.se

https://doi.org/10.18280/ijsdp.160306

Received: 5 March 2021

Accepted: 20 May 2021

\section{Keywords:}

water consumption, optimal water demand, Euphrates River, Al-Anbar province

\begin{abstract}
Water is an essential source of sustaining life and used in generating electricity, agriculture, industry, and the daily domestic uses. This study was prepared to determine the water consumption of Anbar Province in the west of Iraq according to agricultural, industrial, and domestic demand. In addition, the study is evaluating the expected future water consumption by demand sites within study area. The results showed the domestic water demand will increases by $32 \%$ from 267.30 million $\mathrm{m}^{3}$ /year in 2021 to 352.70 million $\mathrm{m}^{3}$ per year in 2035 , with a deficit of $24.5 \%$ in the year 2035 . Furthermore, the study had appeared the agricultural demand was 1404.38 million $\mathrm{m}^{3}$ /year according to the limited cultivated area, which equals $42.93 \%$ from the total available area of 221,250 hectares. The agricultural demand increases to 2611 million $\mathrm{m}^{3}$ /year when uses all available area, and this cause occurs deficit in water demand reach to 1591 and 1715 million $\mathrm{m}^{3}$ /year in the years 2030 and 2035 respectively. In contrast, the study referred to necessary apply other irrigation methods as drip and sprinkler irrigation, which has high irrigation efficiency. In addition, using lined channels and pipes to transport water to reduce losses by leaching and evaporation.
\end{abstract}

\section{INTRODUCTION}

Most of the world's water are saltwater 97.5\%, which represents $70 \%$ of the surface of the earth, and the remaining $2.5 \%$ represent freshwater. Renewable freshwater resources are limited and non-distributed in equal geographically [1]. The global population is projected to grow by 2.5 billion between 2015 and 2050 from an estimated 7.3 billion to 9.8 billion [2], with more demand on the freshwater, which has already tripled since 1965 , is increasing at a rate of $64 \mathrm{~km}^{3} /$ year [1]. In developing countries where the population is expected to increase by more than $80 \%$ with additional demand of food [3].

Globally, irrigated agriculture is more consumer by $70 \%$ of the available fresh water resources, and reach in some developing country to $95 \%$ [4]. The world needs to increase production of food with less amount of water by applied suitable strategies with increasing water demand. So, the world needs to increase production of food with less amount of water by applied suitable strategies for water saving with increase irrigation efficiently. Water withdrawals for agriculture estimated at $70 \%, 11 \%$ for domestic, and $19 \%$ for industrial [4-6]. Irrigated production is the predominant consumer of water about 3 trillion cubic meters of fully extracted fresh water resources are exploited by the agricultural sector [7]. Iraq like other Arab countries located within arid and semi-arid regions, and characterized by the long summer season with high temperatures and the short winter months from December until the beginning of March with a decrease in temperatures [8].

The study area, Anbar Province, as other Iraq region depends on Euphrates River as the main source to supply water demand for domestic, industrial and Agriculture sector. It located in the west of Iraq, where the Euphrates River entered at Husaybah as in (Figure 1). The Euphrates imports shared between Anbar province and other provinces in the south of Iraq. Therefore, if there decrease in the water imports of river this mean reduce the allocated water to the study area.

The upstream countries Turkey and Syria constructing dams as in (Figure 1) on the Iraq Rivers to meet the local demands for agricultural purposes and electric power generation. Iraq's imports from Turkey, Iran and Syria were $71 \%, 6.9 \%$ and $4 \%$ respectively $[9,10]$.

The aim of Study evaluates the water demand in the present and future with an estimate the available for the goal year 2035 for domestic, industrial and agricultural under declined imports Euphrates River.

\section{MATERIALS AND METHODS}

In this study, the year 2018 used as the base year for calculations and 2035 as the goal year. The census of the previous years used to estimate the domestic demand of study area with estimating the growth rate of the population to estimate the future population census. The cultivated area for the base year 2018-2019 of summer and winter crops with the total land suitable for agriculture and not used from the Anbar Irrigation Directorate $\mathrm{d}$ the Agriculture Directorate. The industrial data collected from the published data of the researchers as the number of factories and water demands. 


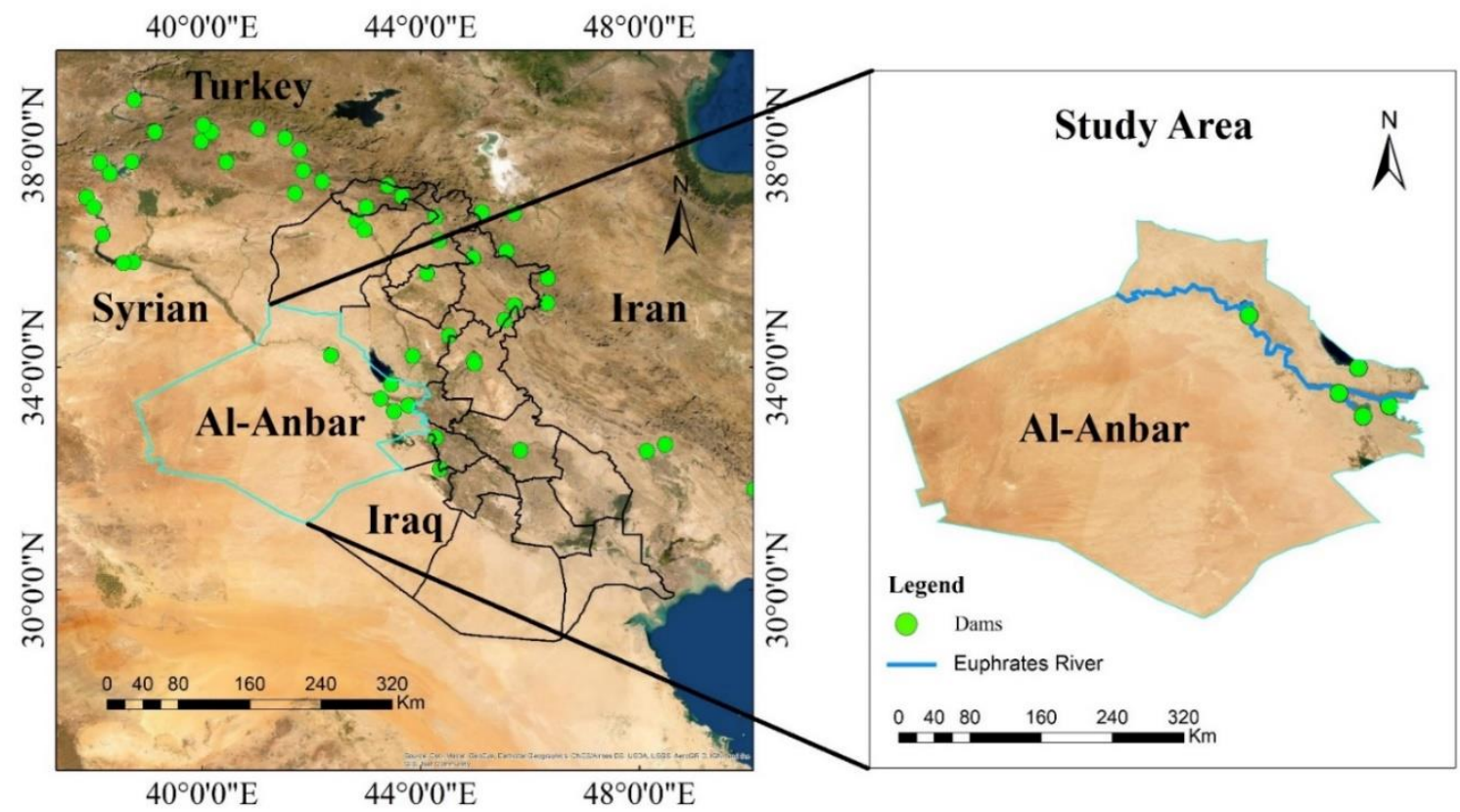

Figure 1. Map of study area with constructed dams

\subsection{Water demand}

\subsubsection{Domestic demand}

The Euphrates River is the primary source for providing domestic water demand by projects and stations located on the banks of the river. The increase in the population census as in (Figure 2) means an increase in the supply to meet the water need of more people. The daily uses of the population as drinking, watering the garden, bathing, preparing food, cleaning the house, and other services, with an average person share is 392 Liter/day [11].

The population growth rate $2 \%$ according to Anbar Statistics Directorate, with used the geometric increase method to estimate the future population census as in the formula [12];

$$
P_{n}=P_{0} \times(1+G)^{n}
$$

where, $P_{n}$ represents the future population number, $G$ represents the growth rate $(\%), \mathrm{P}_{0}$ represents the initial population censes, and $\mathrm{n}$ represents the number of decades between $\mathrm{P}_{\mathrm{n}}$ and $\mathrm{P}_{\mathrm{o}}$

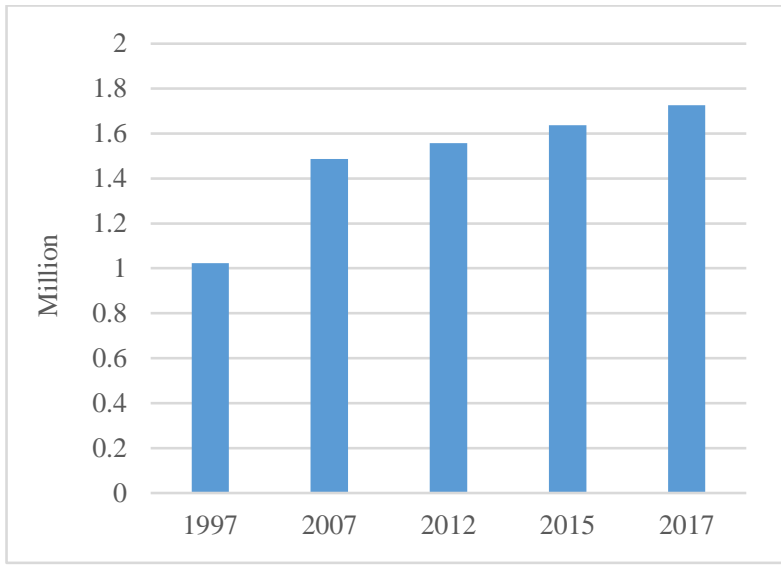

Figure 2. Population census for study area

\subsubsection{Industrial demand}

According to the estimates of the Statistical Directorate for 2018 and the National Investment Commission [13]. Industrial projects differ in water need according to the function of the project, where it divided into small, medium and large projects. The number of large projects in the Anbar province estimated 14 , including the cement, grain, gypsum and flour production projects and others. The small and medium projects about 1688 as blocking, washing construction materials as sand and gravel with the car washing projects established near the river. The amount of water demand for industrial per year for the AlAnbar Province was shown in Table 1.

Table 1. Water demand for industrial $[14,15]$

\begin{tabular}{ccc}
\hline Industry type & Number & $\begin{array}{c}\text { Water Consumption } \mathbf{~ m}^{3} / \\
\text { year })\end{array}$ \\
\hline $\begin{array}{c}\text { Concrete block } \\
\text { factories }\end{array}$ & 55 & 153500 \\
$\begin{array}{c}\text { Sand and gravel } \\
\text { mines }\end{array}$ & 38 & 887750 \\
$\begin{array}{c}\text { Glass and ceramic } \\
\text { factory }\end{array}$ & 1 & 12614400 \\
Phosphate mine & 1 & 28077 \\
Cement industrial & 3 & 396025 \\
factories & & \\
\hline
\end{tabular}

\subsubsection{Irrigation demand}

The surface irrigation method is used to irrigate crops within study area with low efficiency $55 \%$, where the rainfall not enough to meeting the water requirements of crops as in (Figure 3). The surface irrigation used with wheat, barley, onions, yellow and white corn, sunflower and sesame, jets, orchards, and cultivated area with winter and summer vegetables. The agricultural area is 221,250 hectares for the year 2015 . The summer crops represented by $8.86 \%$ and the winter crops represented by $29.7 \%$, in addition to $4.37 \%$ trees. The water requirements of hectare under surface irrigation are $14180 \mathrm{~m}^{3} /$ ha for summer crops, $8030 \mathrm{~m}^{3} /$ ha for winter crops, and $32620 \mathrm{~m}^{3} /$ ha for trees. 
Rainfall (mm) $\square$ T.ave (C) $\quad$ HR.ave (\%)

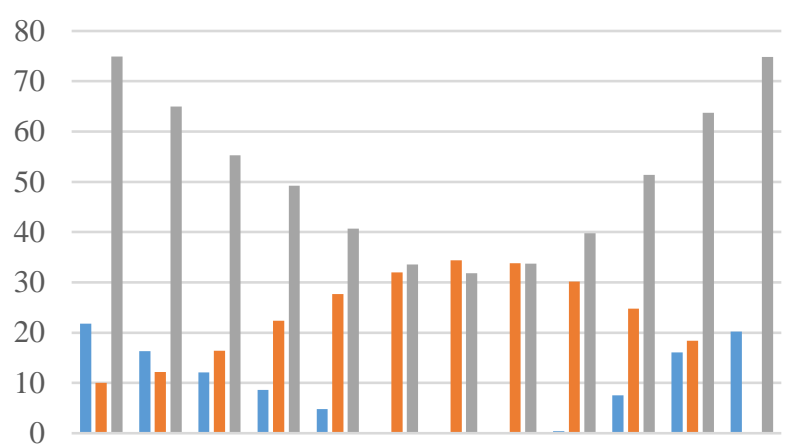

Jan Feb Mar Apr May Jun Jul Aug Sep Oct Nov Dec

Figure 3. Monthly climate data (1986-2016) [14]

\subsection{Water resources}

The Euphrates River is the main source to provide the water demands of the study area. The Euphrates imports began to decline during the previous periods as in (Figure 4) due to the construction of dams by Turkey as GAP project with 22 dams and a total capacity of about $100 \mathrm{Km}^{3}[16,17]$, with the Euphrates Dam by Syrian as in (Figure 1). Haditha Dam, located on the west of the study area, uses to generate electricity and store water for providing water for the study area and the others Iraqi provinces in central and southern Iraq, which considered shared in this water resource. The water imports declined by upstream countries where the Turkish and Syrian dams lead to limited water releases of the Haditha Dam, and caused reducing the water share of the study area as in (Figure 5) and Table 2. The Exponential Forecast was used to estimate the water imports and water share for study area up to the year 2035 to evaluate the future demand.

Table 2. Water demand from the Euphrates River until 2020 (million $\mathrm{m}^{3}$ )

\begin{tabular}{cccc}
\hline Country & Study [18] & Study [19] & Study [20] \\
\hline Turkey & 21600 & 21500 & 14500 \\
Syria & 11995 & 13400 & 5500 \\
Iraq & 17000 & 16000 & 15500 \\
Total need & 50595 & 50900 & 35500 \\
Water Available & 32720 & 31000 & 31680 \\
Balance & $(-17875)$ & $(-19900)$ & $(-3820)$ \\
\hline
\end{tabular}

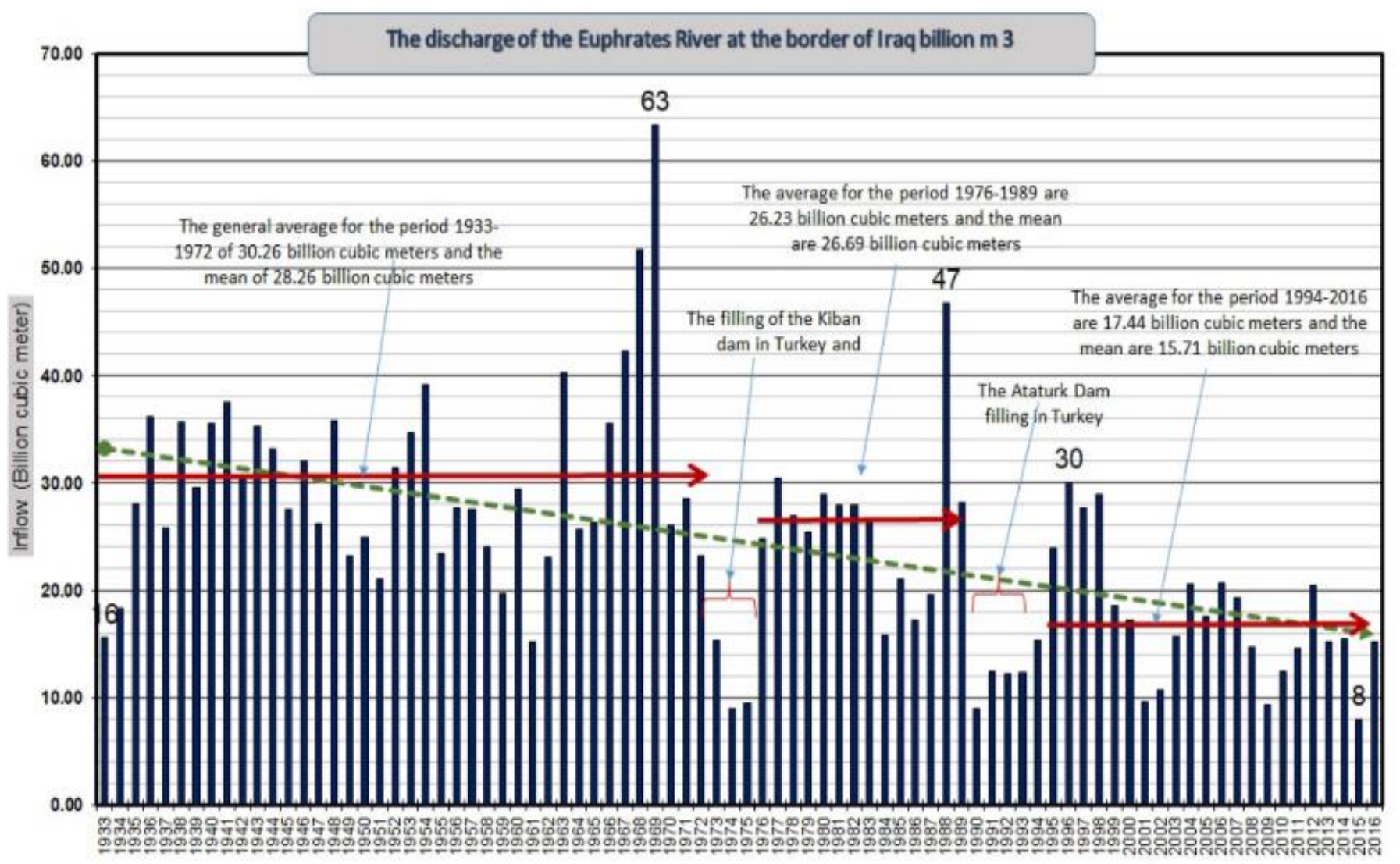

Figure 4. Annual discharge of the Euphrates River at Al-Qaim station [21]

\section{RESULTS AND DISCUSSION}

The results showed that the domestic water demand based on the population census for 2021 by depend on (Figure 3), was $1,875,522$ with a demand per capita of $396 \mathrm{~L} /$ day, which equal 271.08 million $\mathrm{m}^{3} /$ year. Furthermore, the water demand of the industrial was relative and reached 16.08 million $\mathrm{m}^{3} /$ year from Table 2 . In contrast, the agricultural demand was recorded as the most significant demand with 1121 million $\mathrm{m}^{3}$ /year, by depending on the cultivated area with water demands per hectare for crops. Thus, the domestic demand percent $19 \%$ from total demand, $1 \%$ for industrial, and $80 \%$ for agricultural.

The province population was estimated for the future years based on a census of 2017, which was $1,725,914$ with a growth 
rate of $2 \%$. The Eq. (1) was used for the future estimation as shown in Figure 6.

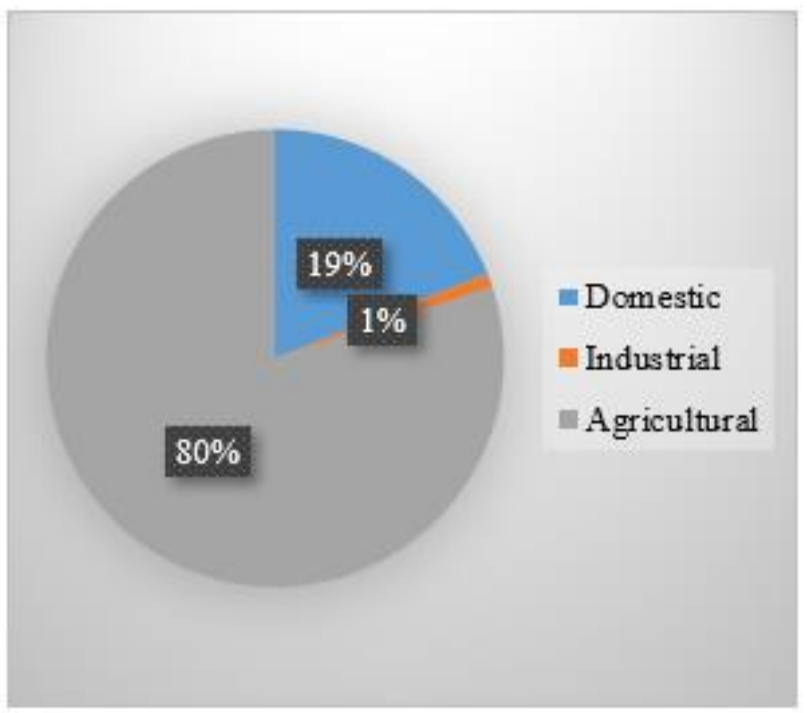

Figure 5. The percentage of water demand

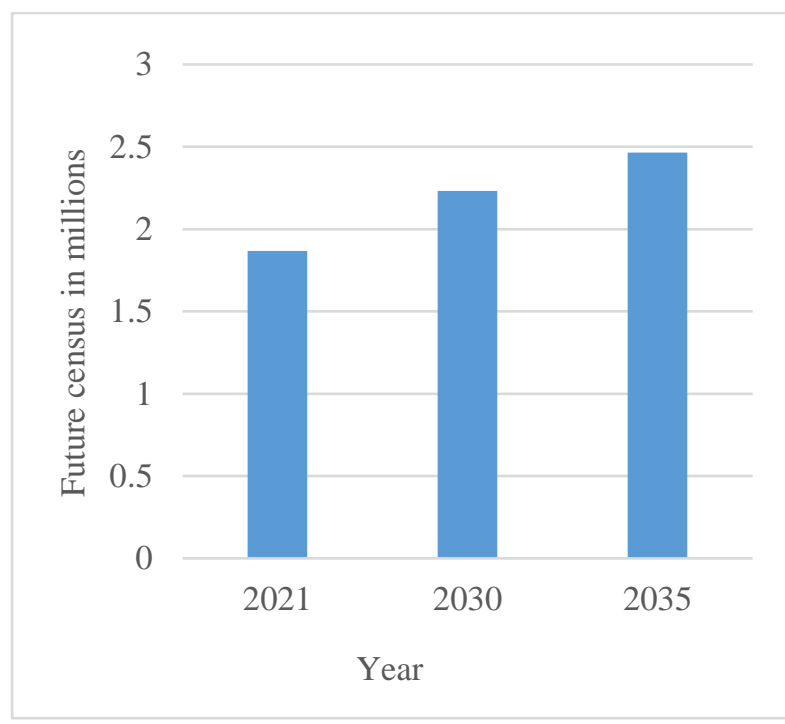

Figure 6. Future census of Anbar province

The domestic water demand in (Figure 7) was calculated by multiply future census by the water demand per person $(392 \mathrm{~L}$ / day). In this study, the future industrial demand was taken as constant, where the consumption is relative compared with domestic and agricultural demand.

The agricultural future demand was taken for all available 221,250 hectares, where the current area is poor and equal $42.93 \%$, distributed $8.86 \%$ for summer crops, $29.7 \%$ for winter crops, $4.37 \%$ for trees as in Table 3. Furthermore, if all available area used 221,250 hectares, the agricultural will demand 2611 million $\mathrm{m}^{3}$ /year as shown in (Figure 8).

In general, the Euphrates River imports began to decrease and continues to reduce significantly as shown in (Figure 4), which leads to a water deficit in Iraq and Anbar Province. It is expected that this deficit will begin in the coming years on the agricultural, especially with the absence of plans to develop and rationalize the water use. From (Figure 4), Iraq lost 14\% of its water imports during the period 1933-1986. Another drops 33\% for 1986-2016 follows this drop. This reduction reflected negatively on the water share of the Anbar province, which was at the end of 2010 about 2200 million $\mathrm{m}^{3} /$ year, to reach by the year 2020 to $1700 \mathrm{~m}^{3} /$ year, meaning the province's share decreased by $23 \%$.

The decline in water imports is hat expected to reach $42 \%$ according to the regression line of the Euphrates' drainage during the previous years. The Anbar water share will be 1275 $\mathrm{m}^{3} /$ year in 2030 and $1120 \mathrm{~m}^{3} /$ year in 2035 and causes a $\mathrm{m}^{3} /$ year deficit and a significant problem with meeting domestic and industrial demand. When taking the province's water share will decrease depending on the water imports of the Euphrates River, and using $80 \%$ for the agricultural, $18 \%$ for the domestic, and $2 \%$ for the industrial, the amount of water will be according to Table 3 .

From Table 3, the province will suffer from a scarcity of water at the agricultural and domestic, which requires reducing the share of the agricultural demand. Water scarcity increases with time. The province will suffer from a deficit in meeting the water requirements at agricultural and domestic demand by $56 \%$ and $28 \%$ respectively in 2030 , with a total shortage of 1672 million cubic meters annually. This deficit will increase until it reaches 1860 in 2035.

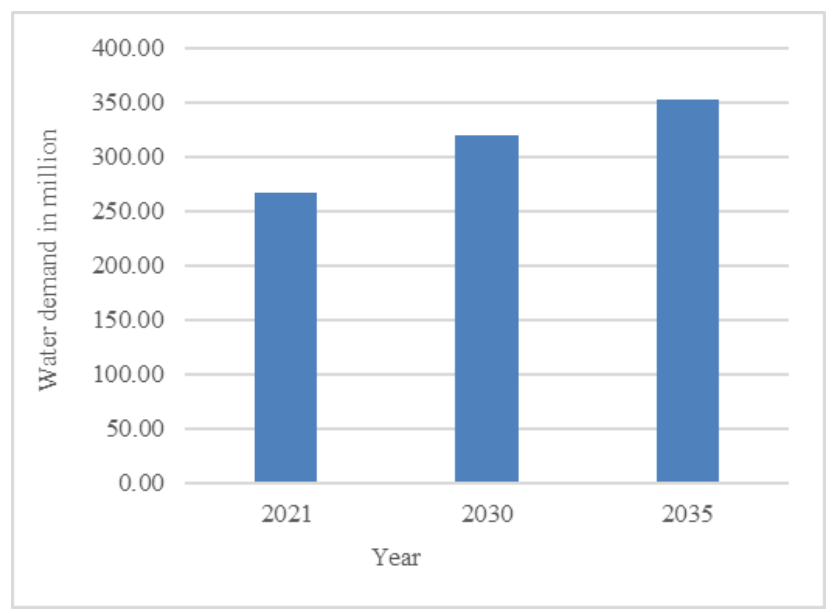

Figure 7. Domestic demand of Anbar governorate

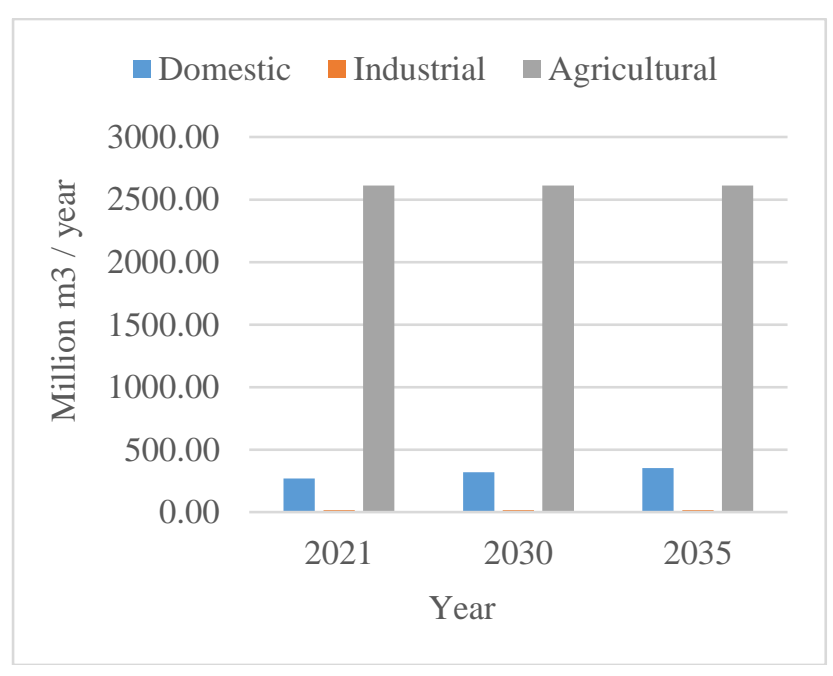

Figure 8. Future water demand (2021-2035) 
Table 3. Water demand with deficit in million $\mathrm{m}^{3} /$ year

\begin{tabular}{|c|c|c|c|c|c|c|}
\hline & \multirow[b]{2}{*}{ Date } & \multicolumn{4}{|c|}{ Annual water demand } & \multirow{2}{*}{$\begin{array}{c}\text { Available and } \\
\text { Deficit } \\
\text { In million } \\
\text { m }^{3} / \text { year }\end{array}$} \\
\hline & & $\begin{array}{l}\text { Total in } \\
\text { million } \\
\text { m }^{3} / \text { year }\end{array}$ & $\begin{array}{c}\text { Domestic } \\
\text { In million } \\
\text { m }^{3} / \text { year } \\
\end{array}$ & $\begin{array}{c}\text { Industrial } \\
\text { In million } \\
\text { m }^{3} / \text { year }\end{array}$ & $\begin{array}{c}\text { Agricultural } \\
\text { In million } \\
\text { m }^{3} / \text { year }\end{array}$ & \\
\hline \multirow{2}{*}{2021} & Water Demand & 1404.38 & 267.30 & 16.08 & 1121 & \multirow{2}{*}{+295.62} \\
\hline & Available Water & 1700 & 306 & 34 & 1360 & \\
\hline \multirow{2}{*}{2030} & Water Demand & 2946.53 & 319.45 & 16.08 & 2611 & \multirow{2}{*}{-1672} \\
\hline & Available Water & 1275 & 229.5 & 25.5 & 1020 & \\
\hline \multirow{2}{*}{2035} & Water Demand & 2979.78 & 352.70 & 16.08 & 2611 & \multirow{2}{*}{-1860} \\
\hline & Available Water & 1120 & 201.6 & 22.4 & 896 & \\
\hline
\end{tabular}

\section{CONCLUSIONS}

The water requirements increase according to the population's growth that requires more food with more water demand daily uses. As the province is dependent on the Euphrates River as the primary resource to meet water demand, the study indicated a deficit in meeting requirements will start with the coming years and increase to reach the 1672 and 1860 million $\mathrm{m}^{3}$ /year by 2030 and 2035, respectively.

Water scarcity is not limited to upstream countries only, but there is mismanagement of the Euphrates River. In the past decades, when neighboring countries worked to increase and construct water installations, projects and development plans were absent in the province and the government.

Agricultural consumes more than $80 \%$ of the province's share of water imports, with the significant waste of water used due to use surface irrigation method. In contrast, there are other irrigation methods as drip and sprinkler irrigation. There is s not using lined channels and pipes to transport water to reduce losses by leaching and evaporation.

It is necessary to reach agreements with the Turkish to increase water releases from Turkish dams to generate electric power that Iraq will buy and thus try to overcome the scarcity of the water crisis that the country could go through in the coming years.

\section{REFERENCES}

[1] Lal, R. (2015). World water resources and achieving water security. Agron. J., 107(4): 1526-1532. https://doi.org/10.2134/agronj15.0045

[2] Walker, R.J. (2016). Population growth and its implications for global security. Am. J. Econ. Sociol., 75(4): 980-1004. https://doi.org/10.1111/ajes.12161

[3] Seckler, D., Amarasinghe, U., Molden, D., de Silva, R., Barker, R. (1998). World water demand and supply, 1990 to 2025: scenarios and issues. Colombo, Sri Lanka: International Irrigation Management Institute (IIMI). vi, 40p. (IWMI Research Report 019 / IIMI Research Report 019). http://dx.doi.org/10.3910/2009.019

[4] FAO. (2017). Water for sustainable food and agriculture water for sustainable food and agriculture. A Report Produced for the G20 Presidency of Germany. http://www.fao.org/3/i7959e/i7959e.pdf.

[5] Sen, R.B. (1963). The state of food and agriculture. Soil Sci., 95(4): 284. https://doi.org/10.1097/00010694196304000-00017.

[6] Najm, A.B.A., Abdulhameed, I.M., Sulaiman, S.O. (2020). Water requirements of crops under various Kc coefficient approaches by using Water Evaluation and
Planning (WEAP). International Journal of Design \& Nature and Ecodynamics, 15(5): 739-748. https://doi.org/10.18280/ijdne.150516

[7] Ahmad, P., Wani, M.R. (2014). Physiological mechanisms and adaptation strategies in plants under changing environment: Volume 1. Springer, New York, NY. https://doi.org/10.1007/978-1-4614-8591-9

[8] Weber, R.W. (2012). Impact of climate change on aeroallergens. Ann. Allergy, Asthma Immunol., 108(5): 294-299. https://doi.org/10.1016/j.anai.2011.11.012

[9] Alkhateb, B.A.A.H. (219). Water deficit in Iraq: Causes and solutions. Acta Sci. Agric., 3(11): 71-72. https://doi.org/10.31080/asag.2019.03.0687

[10] Kamel, A.H., Sulaiman, S.O., Sulaiby Mustaffa, A. (2013). Study of the effects of water level depression in Euphrates river on the water quality. J. Civ. Eng. Archit., 7(2): $\quad 238-247 . \quad$ https://doi.org/10.17265/1934$7359 / 2013.02 .013$

[11] United Nations. (2013). Water in Iraq Factsheet. https://reliefweb.int/sites/reliefweb.int/files/resources/W ater-Factsheet.pdf.

[12] Mekonnen, Y.A. (2018). Population forecasting for design of water supply system in Injibara Town, Amhara Region, Ethiopia. Civil and Environmental Research, 10(10): 54-65

[13] Anbar Industry and Minerals Sector. (2020). Republic of Iraq, Presidency of the Council of Ministers, National Investment Commission, Anbar Industry and Minerals Sector, The site. https://investpromo.gov.iq/all-sectoranbar-province/.

[14] Al Dulaimy, S.L.M. (2018). Water resources in the Ramadi district and their importance in agricultural production. Thesis Submitted to the department of Geography, College of Education 9 University of Anbar, Iraq.

[15] Mohammed, A.H. (2020). Spatial Analysis of Large Manufacturing Facilities stalled in Province of (Baghdad, Basra, Anbar): A study in the Geography of Industry. Thesis is submitted to the Council of the College of Education for Humanities - University of Anbar, Iraq.

[16] Al-Ansari, N.A. (2013). Management of water resources in Iraq: Perspectives and prognoses. Engineering, 5(8): 667-684. https://doi.org/10.4236/eng.2013.58080

[17] Sulaiman, S.O., Al-Dulaimi, G., Al Thamiry, H. (2018). Natural rivers longitudinal dispersion coefficient simulation using hybrid soft computing model. In 2018 11th International Conference on Developments in eSystems Engineering (DeSE), pp. 280-283. https://doi.org/10.1109/DeSE.2018.00056

[18] Altinbilek, H.D. (1997). Water and land resources development in Southeastern Turkey. Int. J. Water 
Resour.

Dev.,

13(3):

311-332.

https://doi.org/10.1080/07900629749719

[19] Kliot, N. (2005). Water resources and conflict in the Middle East. Routledge.

[20] Kolars, J. (1994). Problems of international river management: the case of the Euphrates. Int. Waters
Middle East from Euphrates-Tigris to Nile, pp. 44-94.

[21] Sulaiman, S.O., Kamel, A.H., Sayl, K.N., Alfadhel, M.Y. (2019). Water resources management and sustainability over the Western desert of Iraq. Environ. Earth Sci., 78(16): 495. https://doi.org/10.1007/s12665-019-8510-y 